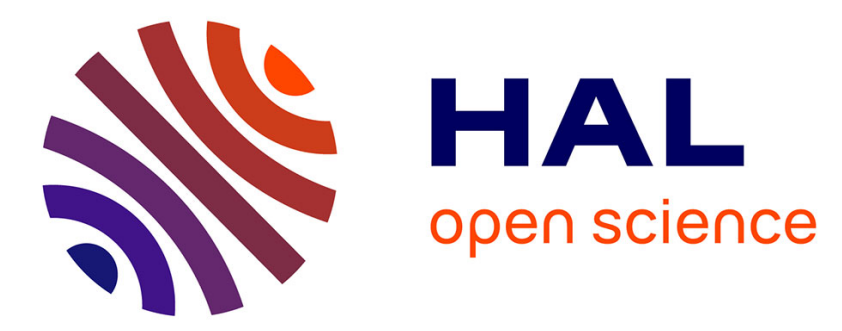

\title{
Novel Aryltriazole Acyclic C-Azanucleosides as Anticancer Candidates
}

Yanhua Zhang, Yun Lin, Qianqian Hou, Xi Liu, Sabrina Pricl, Ling Peng, Yi Xia

\section{- To cite this version:}

Yanhua Zhang, Yun Lin, Qianqian Hou, Xi Liu, Sabrina Pricl, et al.. Novel Aryltriazole Acyclic C-Azanucleosides as Anticancer Candidates. Organic \& Biomolecular Chemistry, 2020, 10.1039/d0ob02164d . hal-03041312

\section{HAL Id: hal-03041312 https://hal-amu.archives-ouvertes.fr/hal-03041312}

Submitted on 4 Dec 2020

HAL is a multi-disciplinary open access archive for the deposit and dissemination of scientific research documents, whether they are published or not. The documents may come from teaching and research institutions in France or abroad, or from public or private research centers.
L'archive ouverte pluridisciplinaire HAL, est destinée au dépôt et à la diffusion de documents scientifiques de niveau recherche, publiés ou non, émanant des établissements d'enseignement et de recherche français ou étrangers, des laboratoires publics ou privés. 
Novel Aryltriazole Acyclic C-Azanucleosides as Anticancer

\section{Candidates}

Yanhua Zhang ${ }^{\mathrm{a} \#}$, Yun Lin ${ }^{\mathrm{a} \#}$, Qianqian $\mathrm{Hou}^{\mathrm{a}}, \mathrm{Xi} \mathrm{Liu}^{\mathrm{a}}$, Sabrina Pricl ${ }^{\mathrm{b}, \mathrm{c}}$, Ling Peng ${ }^{\mathrm{d}}$, Yi

$$
\mathrm{Xia}^{\mathrm{a} *}
$$

${ }^{\text {a }}$ Chongqing Key Laboratory of Natural Product Synthesis and Drug Research, School of Pharmaceutical Sciences, Chongqing University, Chongqing, 401331, China.

b Molecular Biology and Nanotechnology Laboratory (MolBNL@UniTS), DEA, University of Trieste, 34127 Trieste, Italy

${ }^{\mathrm{c}}$ Department of General Biophysics, Faculty of Biology and Environmental Protection, University of Lodz, 90-236 Lodz, Poland

d Aix-Marseille Université, CNRS, Centre Interdisciplinaire de Nanoscience de Marseille (CINaM), UMR 7325, Equipe Labellisé par La Ligue, 13288 Marseille, France

*Corresponding Author

Dr. Yi XIA, Email: yixia@,cqu.edu.cn

\# These authors contribute equally to this work 


\section{Abstract:}

Nucleoside analogues represent an important class of drug candidates. With the aim of searching for novel bioactive nucleosides, we developed an efficient synthetic way to construct a series of aryl 1,2,3-triazole acyclic $C$-azanucleosides via Huisgen 1,3dipolar cycloaddition. The aryl 1,2,3-triazole motifs within these azanucleosides showed coplanar features, suggesting they could act as surrogates for large planar aromatic systems or nucleobases. Moreover, several aryltriazole acyclic $C$ azanucleosides bearing long alkyl chains exhibited potent antiproliferative activity against various cancer cell lines via induction of apoptosis. Most interestingly, the lead compound significantly down-regulated the key proteins involved in the heat shock response pathway, representing the first anticancer acyclic azanucleoside with such a mode of action. These novel aryl 1,2,3-triazole cyclic $C$-azanucleosides therefore serve as promising paradigms for further exploring anticancer drug candidates. 


\section{Introduction}

Nucleoside analogues are synthetic compounds which mimic natural nucleosides. They constitute an important class of drugs for the treatment of various diseases, and mainly act by interfering with the metabolism and function of endogenous nucleosides. ${ }^{1}$

Over 30 nucleoside analogues such as ribavirin and acyclovir (Figure 1) have been used in clinics to treat viral and fungal infections as well as cancers. Recently, remdesivir, a nucleotide analogue, has been evaluated and approved urgently as an antiviral agent to treat patients diagnosed with coronavirus disease 2019 (COVID-19), ${ }^{2,3}$ with the aim of fighting against the severe global pandemic. ${ }^{4}$ Also, ribavirin, a broad-spectrum antiviral nucleoside drug, has been found to modulate the proteins that interact with SARS-CoV2, hence emerging as a potential candidate for COVID-19 therapy. ${ }^{5,6}$ Consequently, search for novel nucleoside drug candidates to combat life-threatening diseases remains an active and appealing area in drug development., ${ }^{7,8}$

In principle, nucleoside analogues can be conceived via altering the nucleobase, the sugar moiety, or both. Among them, azanucleosides are sugar-modified analogues that are characterized by bioisosteric replacement of the oxygen in the ribose sugar with a nitrogen. ${ }^{9,} 10$ The incorporation of nitrogen not only improves the stability of the resulting carbocyclic nucleosides, but also imparts an additional hydrogen bond donor, thus increasing the interactions between the nucleoside analogue and its biological targets. ${ }^{8}$ To date, many azanucleosides have displayed versatile biological activities, including anticancer, antiviral and antimicrobial activity. ${ }^{10}$ For example, forodesine exhibits potent efficacy against T-cell malignancies by inhibiting human purine 
nucleoside phosphorylase (PNP), and it is approved in Japan for treatment of relapsed/refractory peripheral T-cell lymphoma (PTLC). ${ }^{11}$ Galidesivir, an agent exhibiting broad-spectrum antiviral activity against RNA viruses by inhibiting the function of viral RNA polymerase, is currently in phase I trials to treat patients with Ebola infection. ${ }^{12,} 13$ In 2012, the prodrug of phosphonate acyclic azanucleoside analogue (ImmHP) was reported to be capable of blocking the proliferation of Plasmodium falciparum by inhibiting hypoxanthine-guanine-xanthine phosphoribosyltransferase (HGXPRT). ${ }^{14}$ Therefore, development of novel azanucleoside analogues is a promising approach to find therapeutic agents against various diseases.

In our continuing research program to identify bioactive nucleoside analogues, we are interested in developing novel nucleoside derivatives bearing an unnatural base, such as a triazole heterocycle. This is because triazole heterocycles are universe bases able to pair with all natural nucleobases, but also because triazole nucleosides are expected not to be susceptible to nucleoside metabolic degradation and exhibit good in vivo stability. ${ }^{15}$ Triazole nucleoside analogues show potent biological activity against cancer and viruses. ${ }^{16-20}$ A notable example of a triazole nucleoside is ribavirin, which is the first synthetic 1,2,4-triazole nucleoside drug with broad-spectrum antiviral activity and has also shown potential as a cancer therapy in drug repurposing studies. ${ }^{21,22}$ Recently, SRO-91, a 1,2,3-triazole nucleoside ribavirin analogue, exhibited a more potent antiproliferative activity against different cancer cell lines and a lower cytotoxicity than ribavirin. ${ }^{23}$ Our previous work on 1,2,4-triazole nucleosides that bear 
aromatic moieties on nucleobases identified their promising anticancer activity and unique mechanisms of action, such as targeting heat shock response (HSR) pathway, inhibition of the expression of androgen receptors and stimulation of the immune response. ${ }^{24-27}$ These results further highlight the potential of triazole nucleosides and inspire us to develop novel triazole nucleosides as anticancer drug candidates.

Considering the unique structures and potent biological activity of azanucleosides and triazole nucleosides, we were curious about the anticancer potential of triazole azanucleosides which combine triazole nucleobases and azasugar moieties. As the $C$ nucleoside bearing a carbon-carbon $(\mathrm{C}-\mathrm{C})$ bond between the sugar moiety and the base is often more stable than its $N$-analogue, thanks to its resistance to the enzymatic and acid-catalyzed hydrolysis. ${ }^{28,}{ }^{29}$ We are interested in developing the aryl 1,2,3-triazole acyclic $C$-azanucleoside $\mathbf{I}$, which has a stable $\mathrm{C}-\mathrm{C}$ glycosylic bond (Figure 1). In this study, we report the synthesis of the 1,2,3-triazole acyclic $C$-azanucleosides I via Huisgen 1,3-dipolar cycloaddition and the evaluation of their anticancer activity against various human cancer cell lines. Interestingly, these novel triazole acyclic azanucleosides yielded effective apoptosis with potent anticancer activity. In addition, the lead compound bearing a long alkyl chain in the triazole base moiety was able to inhibit the HSR pathway, representing the first acyclic azanucleoside with such a mode of action. 
<smiles>Nc1nc2c(ncn2COCCO)c(=O)[nH]1</smiles>

Acyclovir<smiles>O=c1[nH]cnc2c(C3NC(CO)C(O)C3O)c[nH]c12</smiles>

Forodesine<smiles>NC(=O)c1ncn(C2OC(O)C(CO)C(O)C2O)n1</smiles>

Ribavirin<smiles>NC(=O)c1n[nH]nc1C1OC(O)C(O)C1O</smiles>

SRO-91<smiles>Nc1ncnc2c(C3NC(CO)C(O)C3O)c[nH]c12</smiles>

Galidesivir

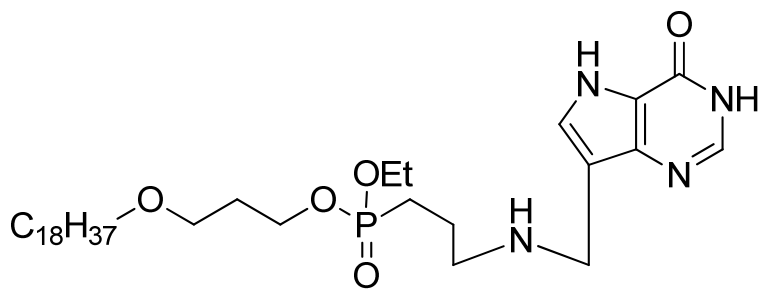

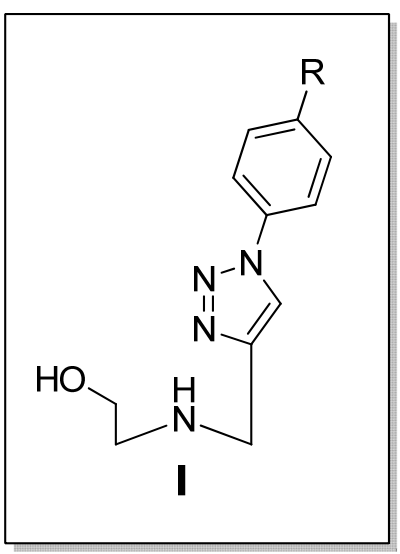

\section{Prodrug of ImmHP}

Figure 1. Chemical structure of acyclovir, ribavirin, SRO-91, forodesine, galidesivir, the prodrug of ImmHP and the aryltriazole acyclic $C$-azanucleoside (I) studied in this work.

\section{Results and discussion}

\section{Chemistry}

We started the synthesis of I with the commercially available 2-oxazolidinone I-1, which underwent $N$-alkylation upon treatment with propargyl bromide and subsequent ring opening under strong basic conditions, generating the alkynyl acyclic azasugar I- 
3 (Table 1). ${ }^{30}$ Using our previously established reaction conditions, ${ }^{31} \mathbf{I}-\mathbf{3}$ was engaged in a copper(I)-catalyzed Huisgen reaction with a variety of aryl azides to regioselectively deliver the 1,4-disubstituted 1,2,3-triazole acyclic $C$-azanucleosides in very good yields (Table 1). The click reaction was well tolerated by a wide range of aryl azide substrates, regardless of whether the substituents in the phenyl ring were aliphatic (entries 1-8 in Table 1), electron-donating or electron-withdrawing groups (entries 9-10 in Table 1), or halogen (entries 11-12 in Table 1).

Table 1. Synthesis of the aryl 1,2,3-triazole acyclic $C$-azanucleosides I.
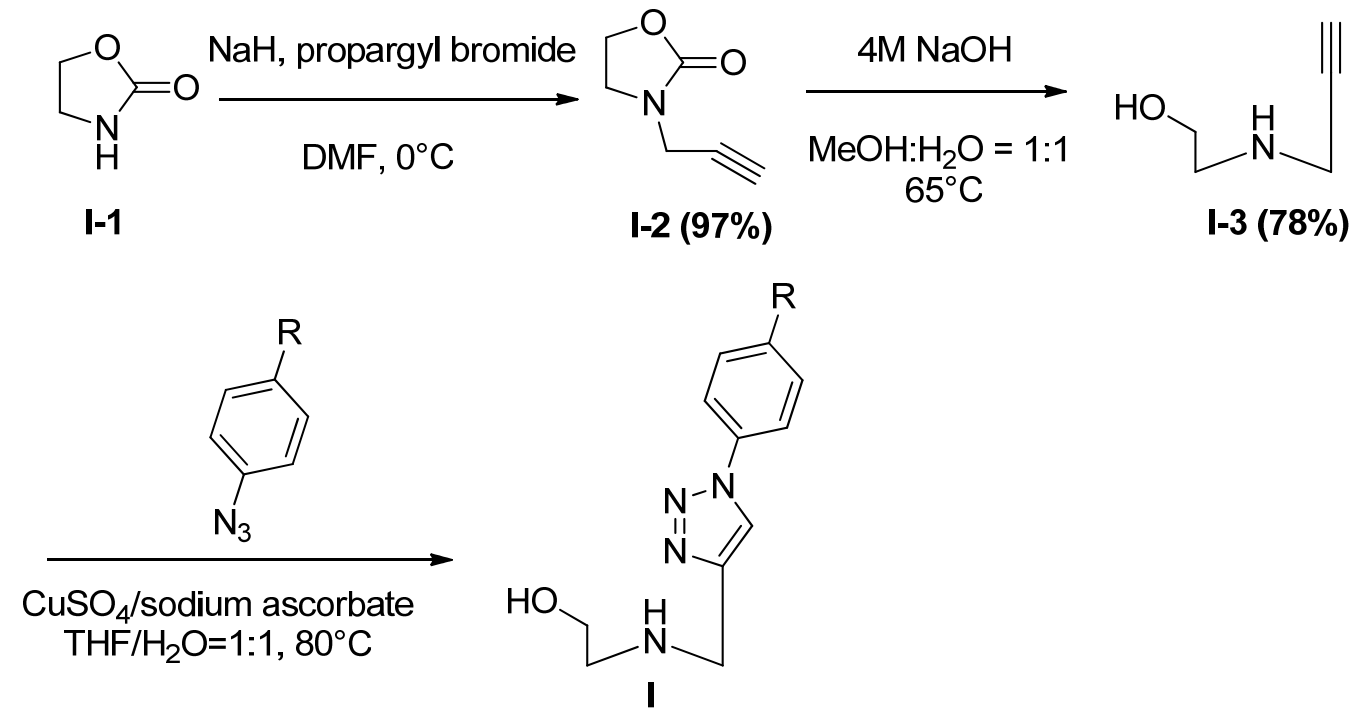

\begin{tabular}{cccccccc}
\hline Entry & $\mathrm{R}$ & Compound & Yield (\%) & Entry & $\mathrm{R}$ & Compound & Yield (\%) \\
\hline $\mathbf{1}$ & $\mathrm{CH}_{3}$ & Ia & 86 & $\mathbf{7}$ & $\mathrm{C}_{14} \mathrm{H}_{29}$ & Ig & 80 \\
$\mathbf{2}$ & $\mathrm{C}_{3} \mathrm{H}_{7}$ & Ib & 84 & $\mathbf{8}$ & $\mathrm{C}_{16} \mathrm{H}_{33}$ & Ih & 79 \\
$\mathbf{3}$ & $\mathrm{C}_{5} \mathrm{H}_{11}$ & Ic & 85 & $\mathbf{9}$ & $\mathrm{CF}_{3}$ & Ii & 83 \\
$\mathbf{4}$ & $\mathrm{C}_{7} \mathrm{H}_{15}$ & Id & 84 & $\mathbf{1 0}$ & $\mathrm{OCH}_{3}$ & $\mathbf{I j}$ & 84 \\
$\mathbf{5}$ & $\mathrm{C}_{10} \mathrm{H}_{21}$ & Ie & 82 & $\mathbf{1 1}$ & $\mathrm{Cl}$ & $\mathbf{I k}$ & 86 \\
$\mathbf{6}$ & $\mathrm{C}_{12} \mathrm{H}_{25}$ & If & 84 & $\mathbf{1 2}$ & $\mathrm{Br}$ & Il & 74 \\
\hline
\end{tabular}


Interestingly, X-ray structural analysis of the obtained acyclic $C$-azanucleoside Ik (Figure 2) revealed that the phenyl ring in Ik and the 1,2,3-triazole ring were almost coplanar. This structural feature is very different from the aryl 1,2,4-triazole nucleoside II where the aryl moiety and the 1,2,4-triazole ring is not co-planar. ${ }^{32,33}$ This difference $^{3}$ may be ascribed to the bulky acyclic chain at 1-position in II (Figure 2), which creates steric hindrance to the adjacent phenyl ring. Therefore, the phenyl ring is rotated out of 1,2,4-triazole ring to release the steric hindrance, exhibiting non-planar organization (Figure 2). Different from II, there's only one hydrogen in the 1,2,3-triazole ring of Ik which can avoid steric hindrance to the aromatic substitution located in the orthoposition (Figure 2).

In order to verify whether all the aryl 1,2,3-triazole acyclic $C$-azanucleosides synthesized in this study also possess of such co-planar structure, we performed computer modeling using Density Functional Theory (DFT) calculations at the B3LYP/6-311++G(d,p) level for the structure optimization of Ia-Il. Notably, our results showed unambiguously that the triazole and the phenyl rings are co-planar in all compounds Ia-Il (Table S1), with the computed structure for Ik matching perfectly with that obtained using X-ray analysis (Figure 2B, Table S2). Further UV spectroscopic study revealed the red shift of the maximum absorption wavelengths of the aryl triazole $C$-azanucleosides compared to that of the non-planar compound II (Figure 2C, Figure S1), providing another evidence of the conjugated systems within these compounds. In addition, NOESY results for Ia, If, Ig and Ij showed that similar strong correlation between the hydrogens at triazole ring and phenyl ring observed for Ik, further 
confirming the co-planarity of these compounds (Figure S2). Collectively, all these results suggest that the phenyl 1,2,3-triazolyl unit may be an interesting motif for mimicking conjugated or enlarged nucleobases.

A
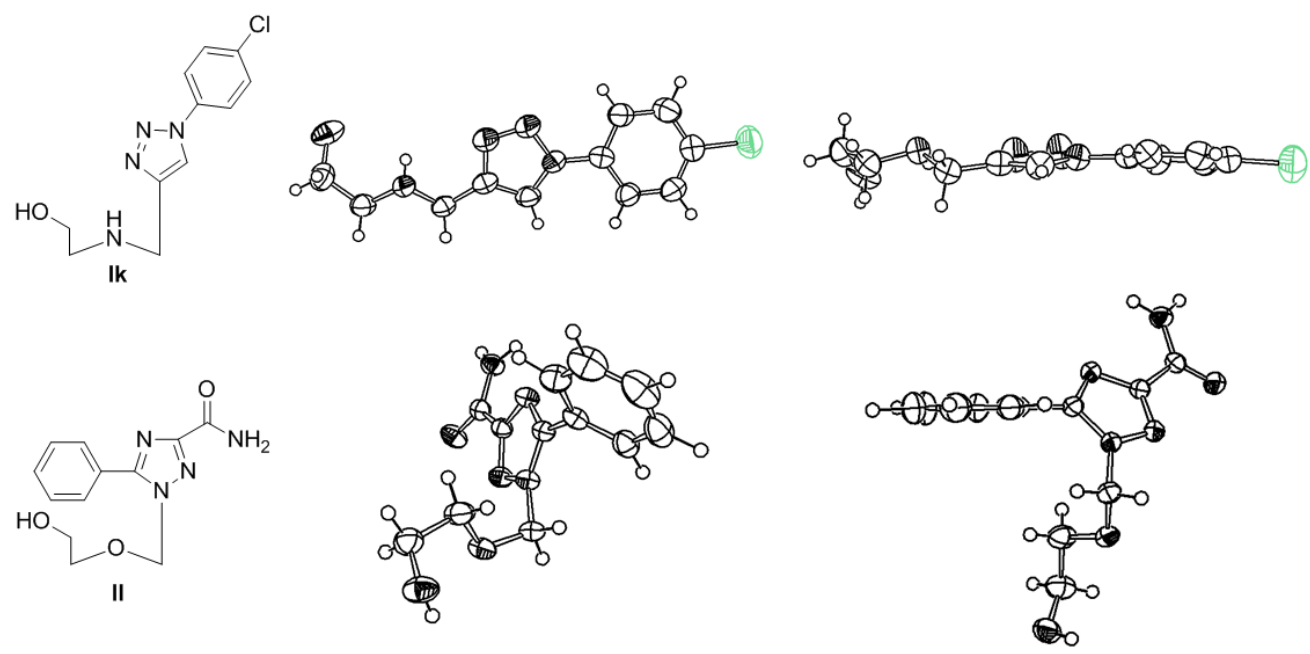

B
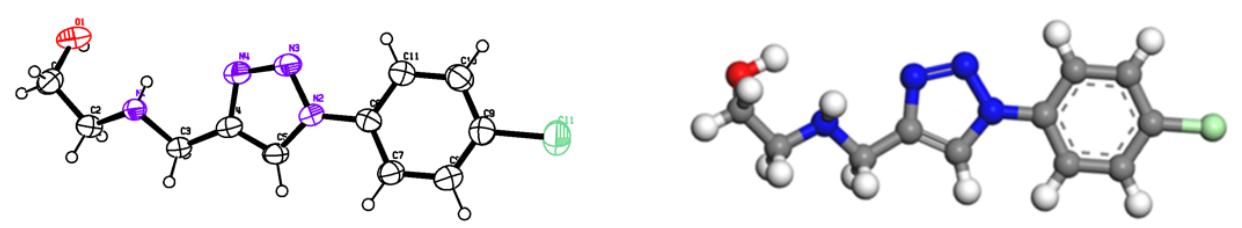

C

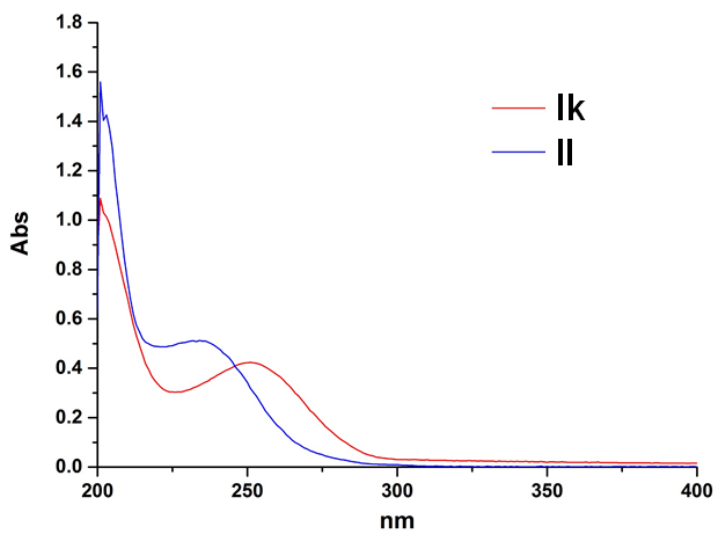

Figure 2. (A) X-ray structures of Ik and the acyclic aryl 1,2,4-triazole nucleoside II.

The green sphere in Ik represents chloride atom. (B) Comparison between experimental (X-ray, left) and calculated (B3LYP/6-311++G(d,p), right) structures for compound Ik.

(C) UV spectra of Ik and II in $\mathrm{MeOH}(50 \mu \mathrm{M})$ was recorded on Agilent Cary 60 UVVis Spectrophotometer within the spectral region of 200-400 $\mathrm{nm}$. 


\section{Antiproliferative activity against human cancer cells}

We then assessed the antiproliferative activity of all synthesized acyclic $C$ azanucleosides against different human cancer cell lines using MTT assay. Table 2 presents the $\mathrm{IC}_{50}$ data obtained for Panc-1 and BxPC-3 (pancreatic cancer), HepG2 (liver cancer), PC-3 (prostate cancer), SKOV3 (ovarian cancer) and HeLa (cervical cancer) cells. As shown in Table 2, the incorporation of a hydrophobic alkyl chain on the triazole nucleobase of the acyclic $C$-azanucleosides notably impacted on the anticancer activity. The nucleosides bearing shorter C1-C3 alkyl chains did not inhibit cancer cell growth (entries 1-2 in Table 2). As the chain length increased from C5 to C14, the corresponding nucleosides showed increasing antiproliferative activity against the various cancer cell lines (entries 3-7 in Table 2), with compound If bearing a C12 alkyl chain exhibiting the most potent activity. This finding agrees with results from our previous studies showing that long alkyl substituents exhibit dramatically increased anticancer activity for 1,2,4-triazole nucleoside analogues. ${ }^{25}$ This seemingly minor structural modification could lead to a significant difference in antiproliferation activity of these nucleoside analogues, indicating the importance of the alkyl chain. To further support our hypothesis, we did the in silico pharmacokinetic property prediction in compounds Ia-Il. The data showed that the compounds with long alkyl chain, such as Ie-Ih, have relatively higher values of $\log$ P (Table S3), indicating their greater hydrophobicity, therefore eventually better membrane-permeability. While the compounds without such alkyl chain, such as Ik, was predicted with lower $\log$, 
suggesting its less cell membrane permeability, which might therefore lead to poor activity. It is to note that compound Ih bearing a $\mathrm{C} 16$ alkyl chain displayed significantly reduced activity compared to If and Ig. This could be possibly explained that the long alkyl chain of C16 may make Ih too lipophilic to be taken up by the cancer cells for effective activity. Altogether, our study highlights the importance of modulating the alkyl chain length to achieve the desired activity.

Table 2. Antiproliferative activity of triazole acyclic $C$-azanucleosides I tested on human cancer cells issued from pancreatic cancer (Panc-1 and BxPC-3), liver cancer (HepG2), prostate cancer (PC-3), ovarian cancer (SKOV3) and cervical cancer (HeLa).

\begin{tabular}{|c|c|c|c|c|c|c|c|c|}
\hline \multirow{2}{*}{ Entry } & \multirow{2}{*}{ Compd. } & \multirow{2}{*}{$\mathrm{R}$} & \multicolumn{6}{|c|}{$\mathrm{IC}_{50}(\mu \mathrm{M})$} \\
\hline & & & Panc-1 & BxPC-3 & HepG2 & PC-3 & SKOV3 & HeLa \\
\hline 1 & Ia & $\mathrm{CH}_{3}$ & $>50$ & $>50$ & $>50$ & $>50$ & $>50$ & $>50$ \\
\hline 2 & Ib & $\mathrm{C}_{3} \mathrm{H}_{7}$ & $>50$ & $>50$ & $>50$ & $>50$ & $>50$ & $>50$ \\
\hline 3 & Ic & $\mathrm{C}_{5} \mathrm{H}_{11}$ & $30 \pm 0.2$ & $22 \pm 2.7$ & $18 \pm 1.1$ & $>50$ & $39 \pm 2.6$ & $>50$ \\
\hline 4 & Id & $\mathrm{C}_{7} \mathrm{H}_{15}$ & $13 \pm 0.5$ & $8.5 \pm 1.4$ & $9.4 \pm 0.7$ & $20 \pm 0.9$ & $17 \pm 2.2$ & $15 \pm 1.8$ \\
\hline 5 & Ie & $\mathrm{C}_{10} \mathrm{H}_{21}$ & $8.7 \pm 1.0$ & $7.6 \pm 0.4$ & $9.2 \pm 0.2$ & $11 \pm 3.3$ & $9.0 \pm 0.6$ & $9.6 \pm 0.9$ \\
\hline 6 & If & $\mathrm{C}_{12} \mathrm{H}_{25}$ & $4.9 \pm 0.1$ & $6.4 \pm 0.1$ & $4.6 \pm 0.2$ & $11 \pm 3.0$ & $8.7 \pm 1.3$ & $9.3 \pm 0.4$ \\
\hline 7 & Ig & $\mathrm{C}_{14} \mathrm{H}_{29}$ & $5.1 \pm 0.3$ & $6.9 \pm 0.4$ & $5.6 \pm 0.5$ & $19 \pm 3.8$ & $17 \pm 0.8$ & $16 \pm 1.9$ \\
\hline 8 & Ih & $\mathrm{C}_{16} \mathrm{H}_{33}$ & $21 \pm 2.8$ & $20 \pm 1.2$ & $38 \pm 3.0$ & $45 \pm 3.7$ & $19 \pm 0.3$ & $17 \pm 2.6$ \\
\hline 9 & $\mathbf{I i}$ & $\mathrm{CF}_{3}$ & $>50$ & $>50$ & $>50$ & $>50$ & $>50$ & $>50$ \\
\hline 10 & $\mathbf{I j}$ & $\mathrm{OCH}_{3}$ & $>50$ & $>50$ & $>50$ & $>50$ & $>50$ & $>50$ \\
\hline
\end{tabular}




\begin{tabular}{ccccccccc}
11 & Ik & $\mathrm{Cl}$ & $>50$ & $>50$ & $>50$ & $>50$ & $>50$ & $>50$ \\
12 & Il & $\mathrm{Br}$ & $>50$ & $>50$ & $>50$ & $>50$ & $>50$ & $>50$ \\
13 & Ribavirin & & $>50$ & $>50$ & $>50$ & $>50$ & $>50$ & $>50$ \\
\hline
\end{tabular}

\section{Compound If induces apoptotic cell death}

As If represented the most potent lead compound among all the synthesized 1,2,3triazole acyclic $C$-azanucleosides, we therefore investigated its mechanism of action. To study whether the antiproliferative activity of If was attributable to apoptosis, we carried out flow cytometry analysis using annexin V-FITC to stain the apoptotic cells and propidium iodide (PI) to mark the necrotic cells. After being treated with If, the percentage of apoptotic Panc-1 cells increased in a dose-dependent manner, while very few necrotic cells were detected (Figure 3A). These results indicate that If predominantly induces apoptosis in cancer cells with negligible necrosis. To further verify the pro-apoptotic activity of If, we assessed its effects on the anti-apoptotic protein BCL-2 and on the poly ADP-ribose polymerase (PARP), cleavage of which is a biomarker of apoptosis. ${ }^{34,35}$ Upon exposure to If, downregulation of BCL-2 and increased expression of cleaved PARP occurred in both Panc-1 and HepG2 cells (Fig. 3B). These data further confirmed the ability of If to induce apoptosis. Moreover, as If has a long hydrophobic alkyl chain, it may cause permeabilization or damage of the plasma membrane and subsequent release of intracellular contents, resulting in necrosis. To investigate this possibility, we performed an LDH assay to quantify the release of lactate dehydrogenase (LDH), which is an efficient way to validate breakage of the cell 
membrane. ${ }^{36}$ Gratifyingly, If did not cause notable LDH release, even at $100 \mu \mathrm{M}$ (Fig. 3C), further testifying that this compound mainly induced cell death via apoptosis. Aiming to validate whether the other triazole $C$-azanucleoside bearing the long alkyl chain also induced cell death via apoptosis, we performed the same studies on compound Ig, as well as two compounds without long alkyl chain (Ic and Ik) as negative control. Similar to If, Ig was also able to induce potent apoptosis in Panc-1 cells with negligible necrosis (Figure S3), while Ic and Ik could not induce apoptosis even at higher concentration (Figure S4). These results further suggesting that the long alkyl chain in the phenyl group is important in maintaining the anticancer activity of these azanucleosides, probably because the long alkyl chain imparts better cell penetration ability.

A
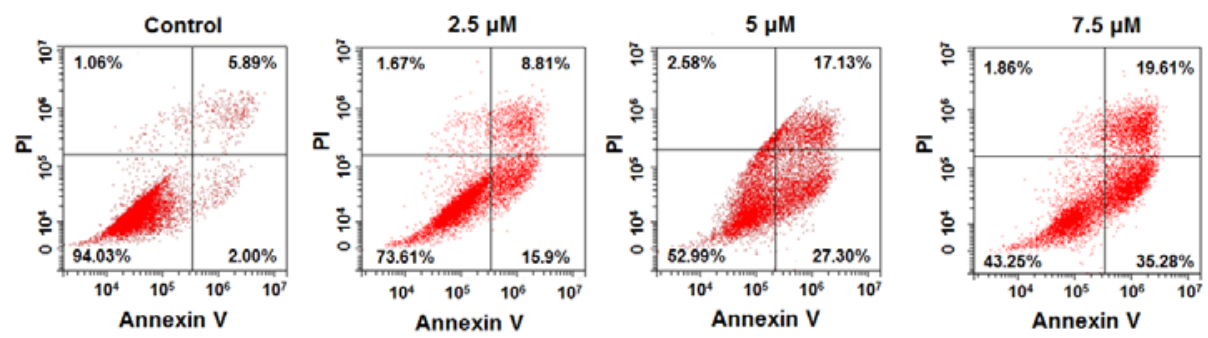

B

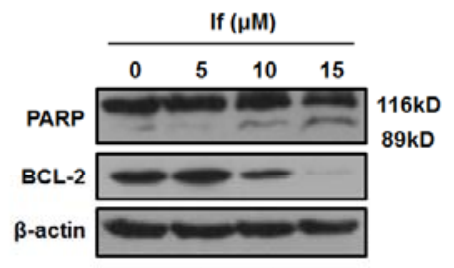

Panc-1

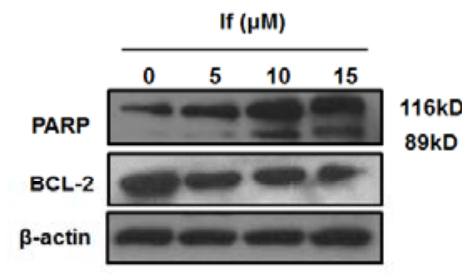

HepG2

C

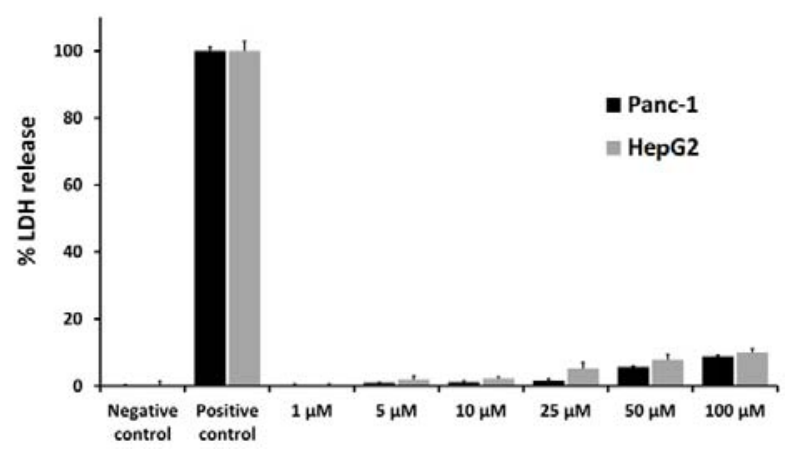


Figure 3. Compound If predominantly induced apoptosis in cancer cells with negligible necrosis. (A) Panc-1 cells were treated with different doses of If for $48 \mathrm{~h}$ and the percentage of cells undergoing apoptosis (Annexin V-positive cells) and necrosis (PIpositive cells) was determined with flow cytometry. Untreated cells were used as the reference control. (B) Compound If efficiently induced the cleavage of PARP and downregulation of BCL-2 in both Panc-1 and HepG2 cells. BCL-2 and PARP protein levels after treatment with different concentrations of compound If were analyzed by use of western blotting, with $\beta$-actin as the reference. (C) Necrosis induced by different concentrations of If in Panc-1 and HepG2 cells was assessed by LDH assays. Control was performed with detergent Triton X-100 and blank medium, and set as $100 \%$ and $0 \%$ LDH release, respectively.

\section{Compound If suppresses the heat shock response (HSR) pathway}

Targeting the heat shock response (HSR) pathway is a promising strategy for cancer treatment, ${ }^{37,38}$ because heat shock factor 1 (HSF1) and several of its downstream heat shock proteins (HSPs) involved in the HSR pathway are highly expressed in cancer cells and play important roles in carcinogenesis and drug resistance. ${ }^{39,}{ }^{40}$ We have previously reported that aryl 1,2,4-triazole nucleosides bearing long alkyl chains exhibited potent anticancer activity by targeting the heat shock response (HSR) pathway. ${ }^{24,25,27}$ As If also contained a long alkyl chain in its structure, we were curious whether this aryl 1,2,3-triazole acyclic $C$-azanucleoside could affect the HSR pathway. We hence examined the effect of If on the protein expression of HSF1 and related HSPs, 
such as HSP27, HSP70 and HSP90 $\alpha$ in both Panc-1 and HepG2 cells, using western blotting. If effectively decreased the expression of HSF1 in a dose-dependent manner (Figure 4), which led to the suppression of HSP27, HSP70 and HSP90 $\alpha$ accordingly. Moreover, If was also able to downregulate the protein level of the eukaryotic translation initiation factor 4E (eIF4E), the client oncoprotein of HSP27. ${ }^{41}$ Altogether, the acyclic $C$-azanucleoside If was able to inhibit several key oncogenic proteins in the HSR pathway to implement its anticancer effect. Similarly to If, the azanucleoside Ig with a 14-carbon alkyl chain also suppressed the expression of HSF1, HSPs and the client protein eIF4E in a dose-dependent manner (Figure S5), while Ic and Ik could not affect these proteins (Figure S4). The above results are in line with those obtained for antiproliferative activities, highlighting that only the aryl triazole $C$-azanucleoside analogues bearing a long alky chain share the similar mode of action for anticancer activity.
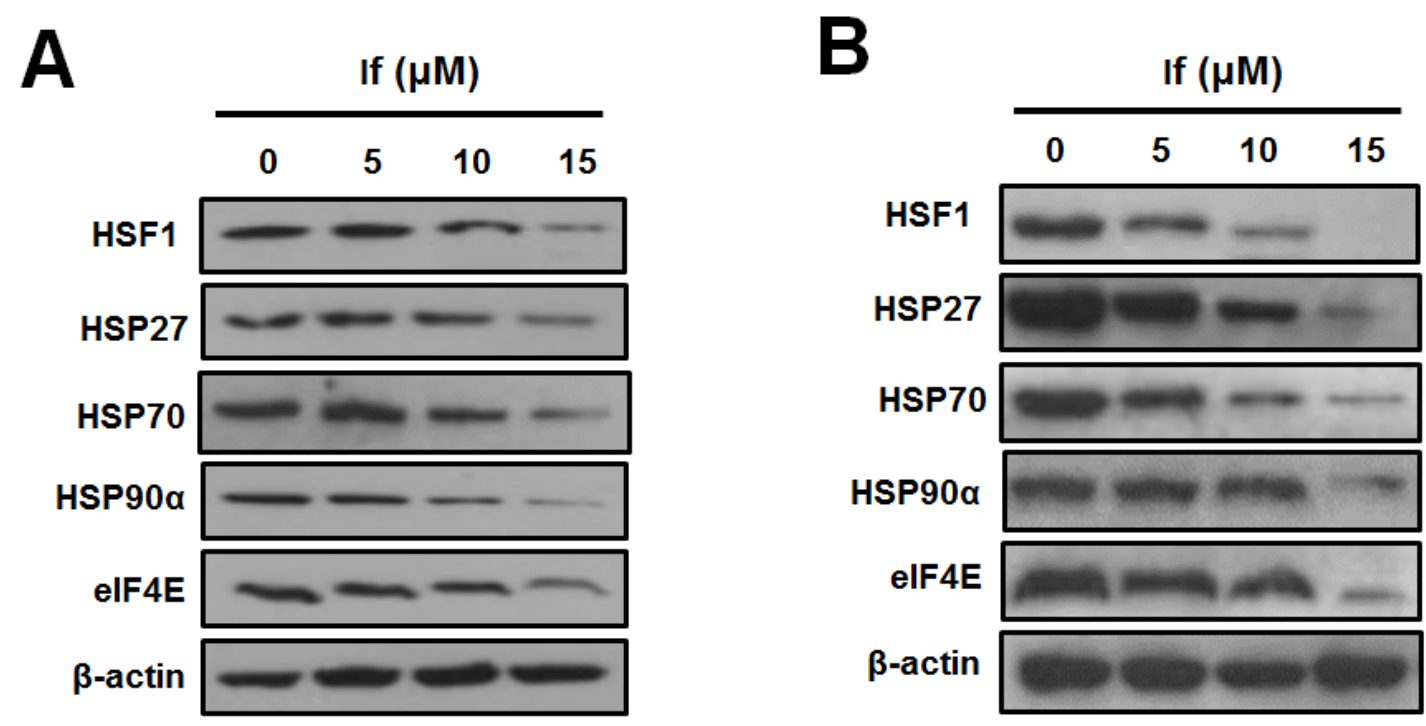

Figure 4. Compound If efficiently inhibited the expression of HSF1, HSP27, HSP70, HSP90 $\alpha$ and eIF4E in Panc-1 (A) and HepG2 cells (B). Panc-1 and HepG2 cells were 
treated with If at indicated concentrations. Protein levels of HSF1, HSP27, HSP70, HSP90 $\alpha$ and eIF4E were then analyzed by western blotting, with $\beta$-actin as the reference.

\section{Conclusion}

In summary, we designed and synthesized a series of novel aryl 1,2,3-triazole acyclic $C$-azanucleosides using a simple and convenient Huisgen 1,3-dipolar cycloaddition reaction. Among them, those bearing alkyl substitutions with appropriate chain length exhibited potent antiproliferative activity against various cancer cell lines. Further studies on the most active lead compound If showed that it promoted apoptosis of cancer cells and was also able to inhibit HSF1, HSPs and their client proteins such as eIF4E, which contributed to its anticancer activity. Collectively, our study has not only initiated the development of novel triazole acyclic azanucleosides but has also revealed for the first time this anticancer mode of action in acyclic azanucleosides. These acyclic azanucleosides constitute therefore promising compounds in our efforts to search for novel nucleoside analogues as potential anticancer candidates.

\section{Experimental section}

\section{Chemistry}

\section{General}

All the aniline and chemical reagents were purchased from Adamas-beta, Energy Chemical and TCI. The aryl azides were prepared according to the reported method. ${ }^{42}$ 
Solvents were purchased from local supplier and used without further purification. All compounds were purified by performing flash chromatography on silica gel (200-300 mesh). ${ }^{1} \mathrm{H}$ NMR and ${ }^{13} \mathrm{C}$ NMR spectra were recorded on Agilent DD2 400-MR. ${ }^{1} \mathrm{H}-{ }^{1} \mathrm{H}$ NOESY spectra of the compounds in $\mathrm{CDCl}_{3}(20 \mathrm{mg} / \mathrm{mL})$ were recorded on Agilent DD2 600-MR. The chemical shifts were recorded in parts per million (ppm) with tetramethylsilane as the internal reference. The ESI-MS was recorded on a Waters Acquity SQ Detecter mass spectrometer or Finigan LCQ mass spectrometer. All MS analysis samples were prepared as solutions in methanol. Analytical HPLC runs were performed on Agilent Technologies 1260 Infinity connected with Inertsil® ODS-3 (Method 1) and Inertsil hypersil C8 (Method 2) by GL sciences Inc, with 1260 VWD VL, wavelength $254 \mathrm{~nm}$. All the samples were dissolved in $\mathrm{MeOH}$. The mobile phase was consisted of a gradient elution of $\mathrm{MeOH}$ and $\mathrm{H}_{2} \mathrm{O}(0.1 \%$ aqueous ammonia). Elution system was the mixture of $\mathrm{MeOH} / \mathrm{H}_{2} \mathrm{O}$ from $20 / 80$ to $100 / 0$ in $15 \mathrm{~min}$ and then kept $100 / 0$ for $20 \mathrm{~min}$. The flow rate was $1.0 \mathrm{~mL} / \mathrm{min}$. Temperature was $30{ }^{\circ} \mathrm{C}$.

Synthesis of 1-(prop-2-ynyl)-oxazolidine-2-one (compound I-2). ${ }^{30}$

2-oxazolidinone (2.0 g, $23 \mathrm{mmol})$ and $\mathrm{NaH}(1.2 \mathrm{~g}, 28 \mathrm{mmol})$ were dissolved in 15 $\mathrm{mL}$ anhydrous DMF at $0{ }^{\circ} \mathrm{C}$. The solution was stirred for 1 hour. Then propargyl bromide (32 mmol, $3.6 \mathrm{~mL}$ ) diluted with $7 \mathrm{~mL}$ of DMF was added drop wise to the solution at $0{ }^{\circ} \mathrm{C}$. After stirred for another 1.5 hour, the solution was quenched with 1 $\mathrm{mL}$ of water carefully, then the solvent was removed in vacuo. The residue was dissolved in $300 \mathrm{~mL}$ dichloromethane. The organic layer was washed with water and 
dried over anhydrous sodium sulfate. The solvent was concentrated under reduced pressure, and the residue was purified by flash chromatography on silica gel (petroleum ether: ethyl acetate, 1:1) to give the compound I-2 (2.8 g) as brown liquid in 97\% yield. ${ }^{1} \mathrm{H}$ NMR (400 MHz, $\left.\mathrm{CDCl}_{3}\right): \delta 4.38\left(\mathrm{t}, J=8.0 \mathrm{~Hz}, 2 \mathrm{H},-\mathrm{OCH}_{2} \mathrm{CH}_{2} \mathrm{~N}-\right), 4.10(\mathrm{~d}, J=2.4$ $\left.\mathrm{Hz}, 2 \mathrm{H},-\mathrm{CH}_{2}-\right), 3.67\left(\mathrm{t}, J=8.0 \mathrm{~Hz}, 2 \mathrm{H},-\mathrm{OCH}_{2} \mathrm{CH}_{2} \mathrm{~N}-\right), 2.32$ (d, $\left.J=2.4 \mathrm{~Hz}, 1 \mathrm{H}, \mathrm{CH}\right)$.

Synthesis of $N$-(prop-2-ynyl)-N-(2-hydroxyethyl)amine (compound I-3). ${ }^{30}$

Compound I-2 (1.3 g, $10.4 \mathrm{mmol})$ was dissolved in $30 \mathrm{~mL}$ of a mixture of $4 \mathrm{M} \mathrm{NaOH}$ in $\mathrm{H}_{2} \mathrm{O} / \mathrm{MeOH}(\mathrm{V}: \mathrm{V}=1: 1)$. Then the solution was stirred and heated to $65{ }^{\circ} \mathrm{C}$ for 2 hours. After cooled to room temperature, the reaction solution was concentrated under reduced pressure and the crude residue was purified by flash chromatography on silica gel $\left(\mathrm{CH}_{2} \mathrm{Cl}_{2}: \mathrm{MeOH}=10: 1\right)$ to give the compound $\mathbf{I}-3$ as yellow liquid $(0.8 \mathrm{~g})$ in $78 \%$ yield.

${ }^{1} \mathrm{H}$ NMR (400 MHz, $\mathrm{CDCl}_{3}$ ): $\delta 3.69$ (t, $J=5.2 \mathrm{~Hz}, 2 \mathrm{H},-\mathrm{OCH}_{2} \mathrm{CH}_{2} \mathrm{~N}-$ ), 3.46 (d, $J=$ $\left.2.0 \mathrm{~Hz}, 2 \mathrm{H},-\mathrm{CH}_{2}-\right), 2.88\left(\mathrm{t}, J=5.2 \mathrm{~Hz}, 2 \mathrm{H},-\mathrm{OCH}_{2} \mathrm{CH}_{2} \mathrm{~N}-\right), 2.24(\mathrm{t}, J=2.0 \mathrm{~Hz}, 1 \mathrm{H}$, $\mathrm{CH})$.

General procedure for the synthesis of compound (I).

Compound I-3 (30 mg, $0.3 \mathrm{mmol})$, phenyl azide (0.36 mmol), copper sulfate pentahydrate $(13 \mathrm{mg}, 0.05 \mathrm{mmol})$, sodium ascorbate $(31 \mathrm{mg}, 0.16 \mathrm{mmol})$ was added to a tube. Then $1.8 \mathrm{~mL}$ THF and $1.8 \mathrm{~mL} \mathrm{H}_{2} \mathrm{O}$ was added to the mixture before sealing the tube. The reaction mixture was stirred and heated to $80^{\circ} \mathrm{C}$ for 2 hours. After cooled to 
room temperature, the reaction solution was concentrated under reduced pressure and the crude residue was purified by flash chromatography on silica gel (dichloromethane: methanol: ammonium hydroxide $=20: 1: 0.5)$ to give the target compound $\mathbf{I}$.

Ia: $60 \mathrm{mg}, 86 \%$, white solid. HPLC: $\mathrm{t}_{\mathrm{R}}=12.692 \mathrm{~min}($ Method 1 , purity $>99 \%), \mathrm{t}_{\mathrm{R}}=$ $12.705 \min ($ Method 2, purity $=98.36 \%) .{ }^{1} \mathrm{H}$ NMR $\left(400 \mathrm{MHz}, \mathrm{CDCl}_{3}\right): \delta 7.93(\mathrm{~s}, 1 \mathrm{H}$, triazole-H), $7.61(\mathrm{~d}, J=8.0 \mathrm{~Hz}, 2 \mathrm{H}$, phenyl-H), $7.32(\mathrm{~d}, J=8.0 \mathrm{~Hz}, 2 \mathrm{H}$, phenyl-H), $4.04\left(\mathrm{~s}, 2 \mathrm{H},-\mathrm{CH}_{2} \mathrm{~N}-\right), 3.73\left(\mathrm{t}, J=4.8 \mathrm{~Hz}, 2 \mathrm{H}, \mathrm{HOCH}_{2} \mathrm{CH}_{2} \mathrm{~N}-\right), 2.91(\mathrm{t}, J=4.8 \mathrm{~Hz}, 2 \mathrm{H}$, $\left.\mathrm{HOCH}_{2} \mathrm{CH}_{2} \mathrm{~N}-\right), 2.42\left(\mathrm{~s}, 3 \mathrm{H},-\mathrm{CH}_{3}\right) .{ }^{13} \mathrm{C} \mathrm{NMR}\left(100 \mathrm{MHz}, \mathrm{CDCl}_{3}\right): \delta 146.45,138.82$, 134.66, 130.20, 120.34, 120.26, 60.60, 50.70, 43.99, 21.07. MS (ESI, m/z): 233.37 [M $+\mathrm{H}]^{+}$. HRMS: calcd for $\mathrm{C}_{12} \mathrm{H}_{16} \mathrm{~N}_{4} \mathrm{NaO},[\mathrm{M}+\mathrm{Na}]^{+}, 255.1216$, found 255.1207.

Ib: $66 \mathrm{mg}, 84 \%$, white solid. HPLC: $\mathrm{t}_{\mathrm{R}}=15.247 \mathrm{~min}($ Method 1, purity $=97.65 \%), \mathrm{t}_{\mathrm{R}}$ $=14.981 \mathrm{~min}(\mathrm{Method} 2$, purity $=96.59 \%) .{ }^{1} \mathrm{H} \mathrm{NMR}\left(400 \mathrm{MHz}, \mathrm{CDCl}_{3}\right): \delta 7.89(\mathrm{~s}, 1 \mathrm{H}$, triazole-H), 7.63 (d, $J=8.0 \mathrm{~Hz}, 2 \mathrm{H}$, phenyl-H), 7.33 (d, $J=8.0 \mathrm{~Hz}, 2 \mathrm{H}$, phenyl-H), $4.03\left(\mathrm{~s}, 2 \mathrm{H},-\mathrm{CH}_{2} \mathrm{~N}-\right), 3.71\left(\mathrm{t}, J=5.2 \mathrm{~Hz}, 2 \mathrm{H}, \mathrm{HOCH}_{2} \mathrm{CH}_{2} \mathrm{~N}-\right), 2.89(\mathrm{t}, J=5.2 \mathrm{~Hz}, 2 \mathrm{H}$, $\left.\mathrm{HOCH}_{2} \mathrm{CH}_{2} \mathrm{~N}-\right), 2.66\left(\mathrm{t}, J=7.6 \mathrm{~Hz}, 2 \mathrm{H}\right.$, phenyl- $\left.\mathrm{CH}_{2}-\right), 1.73-1.63(\mathrm{~m}, 2 \mathrm{H}), 0.96(\mathrm{t}, J=$ $\left.7.2 \mathrm{~Hz}, 3 \mathrm{H},-\mathrm{CH}_{3}\right) .{ }^{13} \mathrm{C} \mathrm{NMR}\left(100 \mathrm{MHz}, \mathrm{CDCl}_{3}\right): \delta 147.05,143.57,134.88,129.63$, $120.39,119.91,60.88,50.77,44.20,37.48,24.40,13.69 . \mathrm{MS}(\mathrm{ESI}, \mathrm{m} / \mathrm{z}): 261.41[\mathrm{M}+$ $\mathrm{H}]^{+}$. HRMS: calcd for $\mathrm{C}_{14} \mathrm{H}_{20} \mathrm{~N}_{4} \mathrm{NaO},[\mathrm{M}+\mathrm{Na}]^{+}, 283.1529$, found 283.1520.

Ic: $74 \mathrm{mg}, 85 \%$, white solid. HPLC: $\mathrm{t}_{\mathrm{R}}=17.102 \min ($ Method 1 , purity $=99.08 \%), \mathrm{t}_{\mathrm{R}}$ $=16.606 \mathrm{~min}(\mathrm{Method} 2$, purity $=96.10 \%) .{ }^{1} \mathrm{H} \mathrm{NMR}\left(400 \mathrm{MHz}, \mathrm{CDCl}_{3}\right): \delta 7.89(\mathrm{~s}, 1 \mathrm{H}$, triazole-H), 7.62 (d, $J=8.0 \mathrm{~Hz}, 2 \mathrm{H}$, phenyl-H), 7.33 (d, $J=8.0 \mathrm{~Hz}, 2 \mathrm{H}$, phenyl-H), $4.02\left(\mathrm{~s}, 2 \mathrm{H},-\mathrm{CH}_{2} \mathrm{~N}-\right), 3.71\left(\mathrm{t}, J=5.2 \mathrm{~Hz}, 2 \mathrm{H}, \mathrm{HOCH}_{2} \mathrm{CH}_{2} \mathrm{~N}-\right), 2.89$ (t, $J=5.2 \mathrm{~Hz}, 2 \mathrm{H}$, 
$\left.\mathrm{HOCH}_{2} \mathrm{CH}_{2} \mathrm{~N}-\right), 2.67$ (t, $J=7.6 \mathrm{~Hz}, 2 \mathrm{H}$, phenyl- $\left.\mathrm{CH}_{2}-\right), 1.67-1.63\left(\mathrm{~m}, 2 \mathrm{H},-\mathrm{CH}_{2-}\right), 1.35-$ $1.33\left(\mathrm{~m}, 4 \mathrm{H},-\left(\mathrm{CH}_{2}\right)_{2}-\right), 0.90\left(\mathrm{t}, J=6.4 \mathrm{~Hz}, 3 \mathrm{H},-\mathrm{CH}_{3}\right) .{ }^{13} \mathrm{C} \mathrm{NMR}\left(100 \mathrm{MHz}, \mathrm{CDCl}_{3}\right): \delta$ $147.03,143.85,134.84,129.57,120.41,119.93,60.88,50.78,44.19,35.42,31.34$, 30.99, 22.48, 14.01. MS (ESI, m/z): $289.41[\mathrm{M}+\mathrm{H}]^{+}$. HRMS: calcd for $\mathrm{C}_{16} \mathrm{H}_{24} \mathrm{~N}_{4} \mathrm{NaO}$, $[\mathrm{M}+\mathrm{Na}]^{+}, 311.1842$, found 311.1832 .

Id: $80 \mathrm{mg}, 84 \%$, white solid. HPLC: $\mathrm{t}_{\mathrm{R}}=18.353 \min ($ Method 1 , purity $=98.60 \%), \mathrm{t}_{\mathrm{R}}$ $=17.749 \min ($ Method 2, purity $=96.87 \%) .{ }^{1} \mathrm{H} \mathrm{NMR}\left(400 \mathrm{MHz}, \mathrm{CDCl}_{3}\right): \delta 7.89(\mathrm{~s}, 1 \mathrm{H}$, triazole-H), 7.62 (d, $J=8.4 \mathrm{~Hz}, 2 \mathrm{H}$, phenyl-H), 7.32 (d, $J=8.4 \mathrm{~Hz}, 2 \mathrm{H}$, phenyl-H), $4.01\left(\mathrm{~s}, 2 \mathrm{H},-\mathrm{CH}_{2} \mathrm{~N}-\right), 3.71\left(\mathrm{t}, J=5.2 \mathrm{~Hz}, 2 \mathrm{H}, \mathrm{HOCH}_{2} \mathrm{CH}_{2} \mathrm{~N}-\right), 2.88(\mathrm{t}, J=5.2 \mathrm{~Hz}, 2 \mathrm{H}$, $\left.\mathrm{HOCH}_{2} \mathrm{CH}_{2} \mathrm{~N}-\right), 2.66\left(\mathrm{t}, J=7.6 \mathrm{~Hz}, 2 \mathrm{H}\right.$, phenyl- $\left.\mathrm{CH}_{2}-\right), 1.68-1.60\left(\mathrm{~m}, 2 \mathrm{H},-\mathrm{CH}_{2}-\right), 1.35-$ $1.26\left(\mathrm{~m}, 8 \mathrm{H},-\left(\mathrm{CH}_{2}\right) 4-\right), 0.88\left(\mathrm{t}, J=6.6 \mathrm{~Hz}, 3 \mathrm{H},-\mathrm{CH}_{3}\right) .{ }^{13} \mathrm{C} \mathrm{NMR}\left(100 \mathrm{MHz}, \mathrm{CDCl}_{3}\right): \delta$ $147.16,143.84,134.88,129.56,120.41,119.83,60.96,50.74,44.23,35.45,31.75$, 31.29, 29.12, 29.09, 22.61, 14.05. MS (ESI, m/z): $317.44[\mathrm{M}+\mathrm{H}]^{+}$. HRMS: calcd for $\mathrm{C}_{18} \mathrm{H}_{29} \mathrm{~N} 4 \mathrm{O},[\mathrm{M}+\mathrm{H}]^{+}, 317.2335$, found 317.2326.

Ie: $89 \mathrm{mg}, 82 \%$, white solid. HPLC: $\mathrm{t}_{\mathrm{R}}=19.854 \min ($ Method 1 , purity $=97.79 \%), \mathrm{t}_{\mathrm{R}}$ $=18.776 \mathrm{~min}(\mathrm{Method} 2$, purity $=98.08 \%) .{ }^{1} \mathrm{H} \mathrm{NMR}\left(400 \mathrm{MHz}, \mathrm{CDCl}_{3}\right): \delta 7.92(\mathrm{~s}, 1 \mathrm{H}$, triazole-H), $7.61(\mathrm{~d}, J=8.0 \mathrm{~Hz}, 2 \mathrm{H}$, phenyl-H), 7.31 (d, $J=8.0 \mathrm{~Hz}, 2 \mathrm{H}$, phenyl-H), $4.01\left(\mathrm{~s}, 2 \mathrm{H},-\mathrm{CH}_{2} \mathrm{~N}-\right), 3.71\left(\mathrm{t}, J=4.8 \mathrm{~Hz}, 2 \mathrm{H}, \mathrm{HOCH}_{2} \mathrm{CH}_{2} \mathrm{~N}-\right), 2.87$ (t, $J=4.8 \mathrm{~Hz}, 2 \mathrm{H}$, $\left.\mathrm{HOCH}_{2} \mathrm{CH}_{2} \mathrm{~N}-\right), 2.66$ (t, $J=7.6 \mathrm{~Hz}, 2 \mathrm{H}$, phenyl- $\left.\mathrm{CH}_{2}-\right), 1.65-1.62\left(\mathrm{~m}, 2 \mathrm{H},-\mathrm{CH}_{2}-\right), 1.33-$ $1.27\left(\mathrm{~m}, 14 \mathrm{H},-\left(\mathrm{CH}_{2}\right) 7-\right), 0.88\left(\mathrm{t}, J=6.6 \mathrm{~Hz}, 3 \mathrm{H},-\mathrm{CH}_{3}\right) .{ }^{13} \mathrm{C} \mathrm{NMR}\left(100 \mathrm{MHz}, \mathrm{CDCl}_{3}\right)$ : $\delta 147.06,143.82,134.86,129.50,120.43,119.93,60.87,50.82,44.22,35.45,31.85$, 31.28, 29.55, 29.43, 29.28, 29.17, 22.64, 14.07. MS (ESI, m/z): $359.48[\mathrm{M}+\mathrm{H}]^{+}$. 
HRMS: calcd for $\mathrm{C}_{21} \mathrm{H}_{35} \mathrm{~N}_{4} \mathrm{O},[\mathrm{M}+\mathrm{H}]^{+}, 359.2805$, found 359.2793.

If: $97 \mathrm{mg}, 84 \%$, white solid. HPLC: $\mathrm{t}_{\mathrm{R}}=20.991 \min ($ Method 1 , purity $=98.72 \%), \mathrm{t}_{\mathrm{R}}=$ $19.448 \min ($ Method 2, purity $=98.85 \%) .{ }^{1} \mathrm{H}$ NMR $\left(400 \mathrm{MHz}, \mathrm{CDCl}_{3}\right): \delta 7.90(\mathrm{~s}, 1 \mathrm{H}$, triazole-H), $7.62(\mathrm{~d}, J=8.0 \mathrm{~Hz}, 2 \mathrm{H}$, phenyl-H), $7.32(\mathrm{~d}, J=8.0 \mathrm{~Hz}, 2 \mathrm{H}$, phenyl-H), $4.02\left(\mathrm{~s}, 2 \mathrm{H},-\mathrm{CH}_{2} \mathrm{~N}-\right), 3.71\left(\mathrm{t}, J=5.2 \mathrm{~Hz}, 2 \mathrm{H}, \mathrm{HOCH}_{2} \mathrm{CH}_{2} \mathrm{~N}-\right), 2.89$ (t, $J=5.2 \mathrm{~Hz}, 2 \mathrm{H}$, $\left.\mathrm{HOCH}_{2} \mathrm{CH}_{2} \mathrm{~N}-\right), 2.66\left(\mathrm{t}, J=7.6 \mathrm{~Hz}, 2 \mathrm{H}\right.$, phenyl- $\left.\mathrm{CH}_{2}-\right), 1.67-1.60\left(\mathrm{~m}, 2 \mathrm{H},-\mathrm{CH}_{2}-\right), 1.34-$ $1.26\left(\mathrm{~m}, 18 \mathrm{H},-\left(\mathrm{CH}_{2}\right) 9-\right), 0.88\left(\mathrm{t}, J=6.6 \mathrm{~Hz}, 3 \mathrm{H},-\mathrm{CH}_{3}\right) .{ }^{13} \mathrm{C} \mathrm{NMR}\left(100 \mathrm{MHz}, \mathrm{CDCl}_{3}\right)$ : $\delta 147.00,143.87,134.87,129.59,120.46,119.91,60.89,50.71,44.18,35.46,31.88$, 31.29, 29.61, 29.55, 29.44, 29.32, 29.18, 22.65, 14.09. MS (ESI, m/z): $387.52[\mathrm{M}+\mathrm{H}]^{+}$. HRMS: calcd for $\mathrm{C}_{23} \mathrm{H}_{39} \mathrm{~N}_{4} \mathrm{O},[\mathrm{M}+\mathrm{H}]^{+}, 387.3118$, found 387.3104 .

Ig: $100 \mathrm{mg}, 80 \%$, white solid. HPLC: $\mathrm{t}_{\mathrm{R}}=22.452 \min ($ Method 1 , purity $=96.77 \%), \mathrm{t}_{\mathrm{R}}$ $=19.993 \mathrm{~min}(\mathrm{Method} 2$, purity $=96.72 \%) .{ }^{1} \mathrm{H} \mathrm{NMR}\left(400 \mathrm{MHz}, \mathrm{CDCl}_{3}\right): \delta 7.90(\mathrm{~s}, 1 \mathrm{H}$, triazole-H), $7.62(\mathrm{~d}, J=8.0 \mathrm{~Hz}, 2 \mathrm{H}$, phenyl-H), 7.33 (d, $J=8.0 \mathrm{~Hz}, 2 \mathrm{H}$, phenyl-H), $4.03\left(\mathrm{~s}, 2 \mathrm{H},-\mathrm{CH}_{2} \mathrm{~N}-\right), 3.72\left(\mathrm{t}, J=5.2 \mathrm{~Hz}, 2 \mathrm{H}, \mathrm{HOCH}_{2} \mathrm{CH}_{2} \mathrm{~N}-\right), 2.89(\mathrm{t}, J=5.2 \mathrm{~Hz}, 2 \mathrm{H}$, $\left.\mathrm{HOCH}_{2} \mathrm{CH}_{2} \mathrm{~N}-\right), 2.67$ (t, $J=7.6 \mathrm{~Hz}, 2 \mathrm{H}$, phenyl- $\left.\mathrm{CH}_{2}-\right), 1.68-1.60\left(\mathrm{~m}, 2 \mathrm{H},-\mathrm{CH}_{2}-\right), 1.32-$ $1.26\left(\mathrm{~m}, 22 \mathrm{H},-\left(\mathrm{CH}_{2}\right)_{11-}\right), 0.88\left(\mathrm{t}, J=6.6 \mathrm{~Hz}, 3 \mathrm{H},-\mathrm{CH}_{3}\right) .{ }^{13} \mathrm{C} \mathrm{NMR}\left(100 \mathrm{MHz}, \mathrm{CDCl}_{3}\right)$ : $\delta 146.83,143.90,134.82,129.58,120.42,119.99,60.82,50.70,44.12,35.47,31.90$, 31.33, 29.68, 29.64, 29.56, 29.46, 29.34, 29.20, 22.68, 14.12. MS (ESI, m/z): 415.55 $[\mathrm{M}+\mathrm{H}]^{+}$. HRMS: calcd for $\mathrm{C}_{25} \mathrm{H}_{43} \mathrm{~N}_{4} \mathrm{O},[\mathrm{M}+\mathrm{H}]^{+}, 415.3431$, found 415.3418.

Ih: $105 \mathrm{mg}, 79 \%$, white solid. HPLC: $\mathrm{t}_{\mathrm{R}}=24.402 \min ($ Method 1, purity $=96.32 \%), \mathrm{t}_{\mathrm{R}}$ $=20.643 \min ($ Method 2, purity $=96.30 \%) .{ }^{1} \mathrm{H} \mathrm{NMR}\left(400 \mathrm{MHz}, \mathrm{CDCl}_{3}\right): \delta 7.92(\mathrm{~s}, 1 \mathrm{H}$, triazole-H), $7.61(\mathrm{~d}, J=8.0 \mathrm{~Hz}, 2 \mathrm{H}$, phenyl-H), 7.31 (d, $J=8.0 \mathrm{~Hz}, 2 \mathrm{H}$, phenyl-H), 
$4.02\left(\mathrm{~s}, 2 \mathrm{H},-\mathrm{CH}_{2} \mathrm{~N}-\right), 3.71\left(\mathrm{t}, J=4.8 \mathrm{~Hz}, 2 \mathrm{H}, \mathrm{HOCH}_{2} \mathrm{CH}_{2} \mathrm{~N}-\right), 2.88(\mathrm{t}, J=4.8 \mathrm{~Hz}, 2 \mathrm{H}$, $\left.\mathrm{HOCH}_{2} \mathrm{CH}_{2} \mathrm{~N}-\right), 2.66\left(\mathrm{t}, J=7.6 \mathrm{~Hz}, 2 \mathrm{H}\right.$, phenyl- $\left.\mathrm{CH}_{2}-\right), 1.65-1.61\left(\mathrm{~m}, 2 \mathrm{H},-\mathrm{CH}_{2}-\right), 1.36-$ $1.26\left(\mathrm{~m}, 26 \mathrm{H},-\left(\mathrm{CH}_{2}\right)_{13}-\right), 0.88\left(\mathrm{t}, J=6.8 \mathrm{~Hz}, 3 \mathrm{H},-\mathrm{CH}_{3}\right) .{ }^{13} \mathrm{C} \mathrm{NMR}\left(100 \mathrm{MHz}, \mathrm{CDCl}_{3}\right)$ : $\delta 146.95,143.84,134.86,129.55,120.39,119.93,60.84,50.78,44.18,35.46,31.89$, 31.29, 29.66, 29.63, 29.55, 29.44, 29.32, 29.19, 22.65, 14.08. MS (ESI, m/z): 443.59 $[\mathrm{M}+\mathrm{H}]^{+}$. HRMS: calcd for $\mathrm{C}_{27} \mathrm{H}_{47} \mathrm{~N}_{4} \mathrm{O},[\mathrm{M}+\mathrm{H}]^{+}, 443.3744$, found 443.3726.

Ii: $71 \mathrm{mg}, 83 \%$, white solid. HPLC: $\mathrm{t}_{\mathrm{R}}=14.063 \min ($ Method 1 , purity $=99.05 \%), \mathrm{t}_{\mathrm{R}}=$ $13.921 \min ($ Method 2, purity $=99.01 \%) .{ }^{1} \mathrm{H}$ NMR $\left(400 \mathrm{MHz}, \mathrm{DMSO}-d_{6}\right): \delta 8.81(\mathrm{~s}$, 1H, triazole-H), 8.17 (d, $J=8.0 \mathrm{~Hz}, 2 \mathrm{H}$, phenyl-H), 7.99 (d, $J=8.0 \mathrm{~Hz}, 2 \mathrm{H}$, phenyl-H), $4.52\left(\mathrm{~s}, 1 \mathrm{H}, \mathrm{HOCH}_{2} \mathrm{CH}_{2} \mathrm{~N}\right), 3.86\left(\mathrm{~s}, 2 \mathrm{H},-\mathrm{CH}_{2} \mathrm{~N}-\right), 3.49(\mathrm{t}, J=5.6 \mathrm{~Hz}, 2 \mathrm{H}$, $\left.\mathrm{HOCH}_{2} \mathrm{CH}_{2} \mathrm{~N}-\right), 2.65$ (t, $\left.J=5.6 \mathrm{~Hz}, 2 \mathrm{H}, \mathrm{HOCH}_{2} \mathrm{CH}_{2} \mathrm{~N}-\right) .{ }^{13} \mathrm{C}$ NMR (100 MHz, DMSO$\left.d_{6}\right): \delta 148.63,139.94,128.84\left(\mathrm{q},{ }^{2} J_{\mathrm{CF}}=32.3 \mathrm{~Hz}\right), 127.59\left(\mathrm{q},{ }^{3} J_{\mathrm{CF}}=3.9 \mathrm{~Hz}\right), 124.26(\mathrm{q}$, $\left.{ }^{1} J_{\mathrm{CF}}=270.5 \mathrm{~Hz}\right), 121.52,120.64,60.72,51.57,44.47 . \mathrm{MS}(\mathrm{ESI}, \mathrm{m} / \mathrm{z}): 287.32[\mathrm{M}+\mathrm{H}]^{+}$. HRMS: calcd for $\mathrm{C}_{12} \mathrm{H}_{14} \mathrm{~F}_{3} \mathrm{~N}_{4} \mathrm{O},[\mathrm{M}+\mathrm{H}]^{+}, 287.1114$, found 287.1107 .

Ij: $63 \mathrm{mg}, 84 \%$, white solid. HPLC: $\mathrm{t}_{\mathrm{R}}=11.603 \mathrm{~min}($ Method 1, purity $=99.19 \%), \mathrm{t}_{\mathrm{R}}=$ $11.716 \min \left(\right.$ Method 2, purity = 99.47\%). ${ }^{1} \mathrm{H}$ NMR (400 MHz, $\left.\mathrm{CDCl}_{3}\right): \delta 7.87(\mathrm{~s}, 1 \mathrm{H}$, triazole-H), 7.62 (d, $J=8.8 \mathrm{~Hz}, 2 \mathrm{H}$, phenyl-H), 7.01 (d, $J=8.8 \mathrm{~Hz}, 2 \mathrm{H}$, phenyl-H), $4.00\left(\mathrm{~s}, 2 \mathrm{H},-\mathrm{CH}_{2} \mathrm{~N}-\right), 3.86\left(\mathrm{~s}, 3 \mathrm{H},-\mathrm{OCH}_{3}\right), 3.71\left(\mathrm{t}, J=4.8 \mathrm{~Hz}, 2 \mathrm{H}, \mathrm{HOCH}_{2} \mathrm{CH}_{2} \mathrm{~N}-\right)$, $2.87\left(\mathrm{t}, J=4.8 \mathrm{~Hz}, 2 \mathrm{H}, \mathrm{HOCH}_{2} \mathrm{CH}_{2} \mathrm{~N}-\right) .{ }^{13} \mathrm{C} \mathrm{NMR}\left(100 \mathrm{MHz}, \mathrm{CDCl}_{3}\right): \delta 159.71,147.06$, 130.46, 122.08, 120.08, 114.71, 60.89, 55.60, 50.83, 44.22. MS (ESI, m/z): 249.34 [M $+\mathrm{H}]^{+}$. HRMS: calcd for $\mathrm{C}_{12} \mathrm{H}_{17} \mathrm{~N}_{4} \mathrm{O}_{2},\left[\mathrm{M}+\mathrm{H}^{+}, 249.1346\right.$, found 249.1340.

Ik: $65 \mathrm{mg}, 86 \%$, white solid. HPLC: $\mathrm{t}_{\mathrm{R}}=13.292 \mathrm{~min}($ Method 1 , purity $=99.51 \%), \mathrm{t}_{\mathrm{R}}$ 
$=13.106 \mathrm{~min}($ Method 2, purity $=98.70 \%) .{ }^{1} \mathrm{H} \mathrm{NMR}\left(400 \mathrm{MHz}, \mathrm{CDCl}_{3}\right): \delta 7.94(\mathrm{~s}, 1 \mathrm{H}$, triazole-H), 7.69 (d, $J=8.8 \mathrm{~Hz}, 2 \mathrm{H}$, phenyl-H), 7.51 (d, $J=8.8 \mathrm{~Hz}, 2 \mathrm{H}$, phenyl-H), $4.02\left(\mathrm{~s}, 2 \mathrm{H},-\mathrm{CH}_{2} \mathrm{~N}-\right), 3.71\left(\mathrm{t}, J=5.2 \mathrm{~Hz}, 2 \mathrm{H}, \mathrm{HOCH}_{2} \mathrm{CH}_{2} \mathrm{~N}-\right), 2.88(\mathrm{t}, J=5.2 \mathrm{~Hz}, 2 \mathrm{H}$, $\left.\mathrm{HOCH}_{2} \mathrm{CH}_{2} \mathrm{~N}-\right) .{ }^{13} \mathrm{C}$ NMR $\left(100 \mathrm{MHz}, \mathrm{CDCl}_{3}\right): \delta 147.58,135.48,134.45,129.92$, 121.56, 119.81, 60.93, 50.77, 44.18. MS (ESI, m/z): $253.30[\mathrm{M}+\mathrm{H}]^{+}, 255.30[\mathrm{M}+$ $2+\mathrm{H}]^{+}$. HRMS: calcd for $\mathrm{C}_{11} \mathrm{H}_{13} \mathrm{ClN}_{4} \mathrm{NaO},[\mathrm{M}+\mathrm{Na}]^{+}, 275.0670$, found $275.0658[\mathrm{M}+$ $\mathrm{Na}]^{+}, 277.0633[\mathrm{M}+2+\mathrm{Na}]^{+}$. Crystallographic data for compound Ik have been deposited at the Cambridge Crystallographic Data Centre (CCDC 1905957).

A single crystal of product Ik suitable for X-ray crystallographic analysis was obtained via slow evaporation the solution of chloroform and methanol. Crystal Data for Ik $(\mathrm{M}=252.70 \mathrm{~g} / \mathrm{mol})$ : triclinic, space group P1 (no.1), $a=4.4944(6) \AA, b=$ 5.4263(7) $\AA, c=12.2978(16) \AA, \alpha=97.735(11)^{\circ}, \beta=94.192(11)^{\circ}, \gamma=92.200(11)^{\circ}, V$ $=296.04(7) \AA^{3}, Z=1, \mathrm{~T}=293(2) \mathrm{K}, \mu(\mathrm{MoK} \alpha)=0.312 \mathrm{~mm}^{-1}$, Dcalc $=1.417 \mathrm{~g} / \mathrm{cm}^{3}$, 2050 reflections measured $\left(7.588^{\circ} \leqslant 2 \Theta \leqslant 57.896^{\circ}\right), 1604$ unique $($ Rint $=0.0157$, $R$ sigma $=0.0381)$ which were used in all calculations. The final $R_{1}$ was 0.0426 (I > $2 \delta(\mathrm{I}))$ and $w R_{2}$ was 0.1135 (all data).

Il: $74 \%$, white solid. HPLC: $\mathrm{t}_{\mathrm{R}}=13.717 \mathrm{~min}($ Method 1 , purity $=98.83 \%), \mathrm{t}_{\mathrm{R}}=13.468$ $\min ($ Method 2, purity $=97.16 \%) .{ }^{1} \mathrm{H}$ NMR $\left(400 \mathrm{MHz}, \mathrm{DMSO}-d_{6}\right): \delta 8.70(\mathrm{~s}, 1 \mathrm{H}$, triazole-H), 7.89 (d, $J=8.4 \mathrm{~Hz}, 2 \mathrm{H}$, phenyl-H), 7.81 (d, $J=8.4 \mathrm{~Hz}, 2 \mathrm{H}$, phenyl-H), $4.52\left(\mathrm{t}, J=5.4 \mathrm{~Hz}, 1 \mathrm{H}, \mathrm{HOCH}_{2} \mathrm{CH}_{2} \mathrm{~N}\right), 3.84\left(\mathrm{~s}, 2 \mathrm{H},-\mathrm{CH}_{2} \mathrm{~N}-\right), 3.51-3.47(\mathrm{~m}, 2 \mathrm{H}$, $\left.\mathrm{HOCH}_{2} \mathrm{CH}_{2} \mathrm{~N}-\right), 2.64$ (t, $\left.J=5.6 \mathrm{~Hz}, 2 \mathrm{H}, \mathrm{HOCH}_{2} \mathrm{CH}_{2} \mathrm{~N}-\right) .{ }^{13} \mathrm{C}$ NMR (100 MHz, DMSO$\left.d_{6}\right): \delta 148.40,136.39,133.18,122.17,121.43,121.31,60.73,51.56,44.50$. MS (ESI, 
m/z): $297.24[\mathrm{M}+\mathrm{H}]^{+}, 299.24[\mathrm{M}+2+\mathrm{H}]^{+}$. HRMS: calcd for $\mathrm{C}_{11} \mathrm{H}_{14} \mathrm{BrN}_{4} \mathrm{O},[\mathrm{M}+$ $\mathrm{H}]^{+}, 297.0345$, found $297.0337[\mathrm{M}+\mathrm{H}]^{+}, 299.0317[\mathrm{M}+2+\mathrm{H}]^{+}$.

\section{UV spectra study}

The tested compounds were dissolved in $\mathrm{MeOH}(50 \mu \mathrm{M})$. Then the UV-Visible spectrum was recorded on Agilent Cary 60 UV-Vis Spectrophotometer within the spectral region of 200-400 $\mathrm{nm}$.

\section{Quantum chemistry calculations}

The molecular structures of compounds Ia-Il were fully optimized using quantum chemistry calculations based on Density Functional Theory (DFT). Specifically, the B3LYP functional ${ }^{43}$ in combination with the $6-311++\mathrm{G}(\mathrm{d}, \mathrm{p})$ basis set was adopted. Optimization was carried out in the gas-phase using Gaussian $16 .^{44}$

In silico pharmacokinetic property predictions

All compounds were subjected to in silicon pharmacokinetic prediction using the online drug-likeness and molecular property prediction software (MolSoft LLC; http:/molsoft.com/mprop/).

\section{Biological assay}

\section{Cell culture}

Human liver cancer HepG2 cell, human prostate cancer PC-3 and ovarian cancer 
SKOV3 cells were purchased from Cell Resource Centre, IBMS, CAMS/PUMC. Human pancreatic cancer Panc-1 cells were the gifts from Prof. Huaizhi Wang (Institute of Hepatopancreatobiliary Surgery, Southwest Hospital, Chongqing). HepG2 cells and Hela cells were grown in Dulbecco's modified eagle's medium (DMEM) (HyClone) supplemented with $10 \%$ fetal bovine serum (FBS). Panc-1 and BxPC-3 cells were grown in Roswell Park Memorial Institute 1640 (RPMI 1640) (GIBCO) supplemented with $10 \%$ FBS. PC-3 cells were grown in Ham's F12 (Kaighn's modification) (GIBCO) supplemented with $10 \%$ FBS. SKOV3 cells were grown in McCoy's 5A (GIBCO) supplemented with $10 \%$ FBS. All cells were incubated at a humidified atmosphere containing $5 \% \mathrm{CO}_{2}$ at $37{ }^{\circ} \mathrm{C}$.

\section{Reagents and Antibodies}

MTT (3-(4,5-dimethylthiazol-2-yl)-2,5-diphenyl tetrazolium bromide) was purchased from Adamas. The annexin V-FITC/ Propidium Iodide PI apoptosis detection kit was purchased from Sangon Biotech (Shanghai, China). The primary antibodies including PARP antibody, BCL-2 antibody, HSF1 rabbit mAb, HSP70 rat mAb, HSP27 rabbit mAb and eIF4E rabbit mAb were all obtained from Cell Signaling Technology (Danvers, MA, USA). The $\beta$-actin rabbit antibody and goat anti-rat (HRP) secondary antibody were purchased from Bioss (Beijing, China). The goat anti-rabbit (HRP) secondary antibody was purchased from Sino Biological Inc. (Beijing, China). The cell lysis buffer, primary antibody dilution buffer and ECL kit were purchased from Beyotime (Shanghai, China). 


\section{Cell growth inhibition assay}

HepG2, Hela, PC-3 and SKOV3 cells were seeded into a 96-well plate at 10000 cells per well, while BxPC-3 and Panc-1 cells at 5000 cells per well, and allowed to adhere overnight. Then the culture medium was removed and replaced with fresh media alone as control or containing various concentrations of the compounds. After indicated treatment, the number of viable cells remained was determined by MTT colorimetric assay at $490 \mathrm{~nm}$. All experiments were done in triplicate and repeated three independent times. The $\mathrm{IC}_{50}$ values were calculated with the software program SPSS 22.0.

Lactate dehydrogenase (LDH) assay.

The LDH assay was measured by using commercial LDH kit (Cytotoxicity Assay Kit, Beyotime). The cancer cells were seeded 10,000 cells per well in 96-well plates, respectively. 24 hours later, the culture medium was removed and replaced with fresh media alone or containing the test compounds. After $1 \mathrm{~h}$ treatment, the plates were centrifuged for 5 minutes in a multiwell plate centrifuge $(400 \mathrm{~g})$, and $120 \mu \mathrm{L}$ supernatant of each well was transferred to a new 96-well plate. The LDH reaction mixture was freshly prepared according to the manufacturer's protocol and $60 \mu \mathrm{L}$ of this mixture was added to each well of the plates containing blank, control, or cells in culture. The plate was incubated at $25{ }^{\circ} \mathrm{C}$ for $30 \mathrm{~min}$. Control was performed with detergent Triton X-100 and blank medium, and set as 100\% and 0\% LDH release, respectively. The relative $\mathrm{LDH}$ release is defined by the ratio of LDH released over 
total LDH in the cells. All samples were performed in triplicate.

Apoptosis and necrosis assay on flow cytometry

The cancer cells were seeded in $60 \mathrm{~mm}$ culture dishes $\left(2.5 \times 10^{5}\right.$ cells/dish $)$ and allowed to adhere and proliferate overnight. Culture medium was then removed and fresh media containing the compound was added. After 48 hours treatment, the cells were harvested and washed with cold PBS. The samples were pelleted again through centrifugation and resuspended in binding buffer. Annexin-V/FITC and propidium iodide (PI) was then added to the cells and the samples were incubated for 10 minutes at room temperature. After staining, flow cytometry was performed on Fluorescence Activated Cell Sorting (Beckman Coulter). Each sample was performed in triplicate.

\section{Western Blotting}

The cancer cells after being treated by the compounds were lysed in lysis buffer. A total of $10-50 \mu \mathrm{g}$ protein were quantified and loaded into the $10 \%$ SDS-PAGE gel. After electrophoresis, the proteins in the gel were transferred to a PVDF membrane. Then the membrane was blocked in 5\% (w/v) skim milk in TBS-T for $1 \mathrm{~h}$ and incubated with the primary antibodies at $4{ }^{\circ} \mathrm{C}$ overnight. The membrane was washed with TBS-T and incubated with HRP-conjugated secondary antibody for $1 \mathrm{~h}$. Specific proteins were detected using an ECL kit.

\section{Supporting Information}

Figure S1-S5, Table S1-S3, ${ }^{1} \mathrm{H},{ }^{13} \mathrm{C}$, and HPLC spectra are included in supporting 
information. (PDF)

\section{Conflicts of interest}

The authors have no conflicts to declare.

\section{Acknowledgement}

This work is supported by the National Natural Science Foundation of China (81502920); Graduate Research and Innovation Foundation of Chongqing, China (CYB19066); CAI YUANPEI Scholarship (201906050187); the Startup Funding for "Hundred Young-Talent Program” Professorship provided by Chongqing University (0236011104412), Chongqing Natural Science Foundation (cstc2015jcyjA10093), Jeunes Talents France-Chine Program (JTFC). This article is based upon work from COST Action CA 17140 "Cancer Nanomedicine from the Bench to the Bedside" supported by COST (European Cooperation in Science and Technology).

\section{Reference}

1. L. P. Jordheim, D. Durantel, F. Zoulim and C. Dumontet, Nat. Rev. Drug Discovery, 2013, 12, 447-464.

2. J. Grein, N. Ohmagari, D. Shin, G. Diaz, E. Asperges, A. Castagna, T. Feldt, G. Green, M. L. Green, F.-X. Lescure, E. Nicastri, R. Oda, K. Yo, E. Quiros-Roldan, A. Studemeister, J. Redinski, S. Ahmed, J. Bernett, D. Chelliah, D. Chen, S. Chihara, S. H. Cohen, J. Cunningham, A. D’Arminio Monforte, S. Ismail, H. Kato, G. Lapadula, 
E. L'Her, T. Maeno, S. Majumder, M. Massari, M. Mora-Rillo, Y. Mutoh, D. Nguyen, E. Verweij, A. Zoufaly, A. O. Osinusi, A. DeZure, Y. Zhao, L. Zhong, A. Chokkalingam, E. Elboudwarej, L. Telep, L. Timbs, I. Henne, S. Sellers, H. Cao, S. K. Tan, L. Winterbourne, P. Desai, R. Mera, A. Gaggar, R. P. Myers, D. M. Brainard, R. Childs and T. Flanigan, N. Engl. J. Med, 2020, 382, 2327-2336.

3. J. Wise, $B M J, 2020, \mathbf{3 6 9}, \mathrm{m} 2610$.

4. E. Dong, H. Du and L. Gardner, Lancet Infect. Dis., 2020, 20, 533-534.

5. D. E. Gordon, G. M. Jang, M. Bouhaddou, J. Xu, K. Obernier, K. M. White, M. J. O’Meara, V. V. Rezelj, J. Z. Guo, D. L. Swaney, T. A. Tummino, R. Hüttenhain, R. M. Kaake, A. L. Richards, B. Tutuncuoglu, H. Foussard, J. Batra, K. Haas, M. Modak, M. Kim, P. Haas, B. J. Polacco, H. Braberg, J. M. Fabius, M. Eckhardt, M. Soucheray, M. J. Bennett, M. Cakir, M. J. McGregor, Q. Li, B. Meyer, F. Roesch, T. Vallet, A. Mac Kain, L. Miorin, E. Moreno, Z. Z. C. Naing, Y. Zhou, S. Peng, Y. Shi, Z. Zhang, W. Shen, I. T. Kirby, J. E. Melnyk, J. S. Chorba, K. Lou, S. A. Dai, I. Barrio-Hernandez, D. Memon, C. Hernandez-Armenta, J. Lyu, C. J. P. Mathy, T. Perica, K. B. Pilla, S. J. Ganesan, D. J. Saltzberg, R. Rakesh, X. Liu, S. B. Rosenthal, L. Calviello, S. Venkataramanan, J. Liboy-Lugo, Y. Lin, X.-P. Huang, Y. Liu, S. A. Wankowicz, M. Bohn, M. Safari, F. S. Ugur, C. Koh, N. S. Savar, Q. D. Tran, D. Shengjuler, S. J. Fletcher, M. C. O’Neal, Y. Cai, J. C. J. Chang, D. J. Broadhurst, S. Klippsten, P. P. Sharp, N. A. Wenzell, D. Kuzuoglu-Ozturk, H.-Y. Wang, R. Trenker, J. M. Young, D. A. Cavero, J. Hiatt, T. L. Roth, U. Rathore, A. Subramanian, J. Noack, M. Hubert, R. M. Stroud, A. D. Frankel, O. S. Rosenberg, K. A. Verba, D. A. Agard, M. Ott, M. 
Emerman, N. Jura, M. von Zastrow, E. Verdin, A. Ashworth, O. Schwartz, C. d'Enfert, S. Mukherjee, M. Jacobson, H. S. Malik, D. G. Fujimori, T. Ideker, C. S. Craik, S. N. Floor, J. S. Fraser, J. D. Gross, A. Sali, B. L. Roth, D. Ruggero, J. Taunton, T. Kortemme, P. Beltrao, M. Vignuzzi, A. García-Sastre, K. M. Shokat, B. K. Shoichet and N. J. Krogan, Nature, 2020, 583, 459-468.

6. G. Li and E. De Clercq, Nat. Rev. Drug Discov., 2020, 19, 149-150.

7. J. Shelton, X. Lu, J. A. Hollenbaugh, J. H. Cho, F. Amblard and R. F. Schinazi, Chem. Rev., 2016, 116, 14379-14455.

8. K. L. Seley-Radtke and M. K. Yates, Antiviral Res., 2018, 154, 66-86.

9. G. Romeo, U. Chiacchio, A. Corsaro and P. Merino, Chem. Rev., 2010, 110, $3337-$ 3370.

10. D. Hernández and A. Boto, Eur. J. Org. Chem., 2014, 2014, 2201-2220.

11. S. Makita, A. M. Maeshima, D. Maruyama, K. Izutsu and K. Tobinai, Onco Targets Ther., 2018, 11, 2287-2293.

12. T. K. Warren, J. Wells, R. G. Panchal, K. S. Stuthman, N. L. Garza, S. A. Van Tongeren, L. Dong, C. J. Retterer, B. P. Eaton, G. Pegoraro, S. Honnold, S. Bantia, P. Kotian, X. Chen, B. R. Taubenheim, L. S. Welch, D. M. Minning, Y. S. Babu, W. P. Sheridan and S. Bavari, Nature, 2014, 508, 402-405.

13. E. De Clercq, Chem. Asian J., 2019, 14, 3962-3968.

14. Keith Z. Hazleton, M.-C. Ho, Maria B. Cassera, K. Clinch, Douglas R. Crump, I. Rosario, Emilio F. Merino, Steve C. Almo, Peter C. Tyler and Vern L. Schramm, Chem. Biol., 2012, 19, 721-730. 
15. D. Loakes, Nucleic Acids Res., 2001, 29, 2437-2447.

16. Y. Xia, F. Qu and L. Peng, Mini-Rev. Med. Chem., 2010, 10, 806-821.

17. C. H. Zhou and Y. Wang, Curr. Med. Chem., 2012, 19, 239-280.

18. S. Raic-Malic and A. Mescic, Curr. Med. Chem., 2015, 22, 1462-1499.

19. J. Zeidler, D. Baraniak and T. Ostrowski, Eur. J. Med. Chem., 2015, 97, 409-418.

20. R. Kaur, A. Ranjan Dwivedi, B. Kumar and V. Kumar, Anticancer Agents Med. Chem., 2016, 16, 465-489.

21. S. Crotty, D. Maag, J. J. Arnold, W. Zhong, J. Y. N. Lau, Z. Hong, R. Andino and C. E. Cameron, Nat. Med., 2000, 6, 1375-1379.

22. J. Casaos, N. L. Gorelick, S. Huq, J. Choi, Y. Xia, R. Serra, R. Felder, T. Lott, R. E. Kast, I. Suk, H. Brem, B. Tyler and N. Skuli, Mol. Cancer Ther., 2019, 18, 1185-1194. 23. N. Sabat, E. Migianu-Griffoni, T. Tudela, M. Lecouvey, S. Kellouche, F. Carreiras, F. Gallier, J. Uziel and N. Lubin-Germain, Eur. J. Med. Chem., 2020, 188, 112009. 24. Y. Xia, Y. Liu, J. Wan, M. Wang, P. Rocchi, F. Qu, J. L. Iovanna and L. Peng, J. Med. Chem., 2009, 52, 6083-6096.

25. Y. Xia, Y. Liu, P. Rocchi, M. Wang, Y. Fan, F. Qu, J. L. Iovanna and L. Peng, Cancer Lett., 2012, 318, 145-153.

26. Y. Xia, M. Wang, O. Demaria, J. Tang, P. Rocchi, F. Qu, J. L. Iovanna, L. Alexopoulou and L. Peng, J. Med. Chem., 2012, 55, 5642-5646.

27. Y. Xia, M. Wang, E. Beraldi, M. Cong, A. Zoubeidi, M. Gleave and L. Peng, Anticancer Agents Med. Chem., 2015, 15, 1333-1340.

28. J. Štambaský, M. Hocek and P. Kočovský, Chem. Rev., 2009, 109, 6729-6764. 
29. E. De Clercq, J. Med. Chem., 2016, 59, 2301-2311.

30. J. Vergnaud, P.-A. Faugeras, V. Chaleix, Y. Champavier and R. Zerrouki, Tetrahedron Lett., 2011, 52, 6185-6189.

31. Y. Xia, W. Li, F. Qu, Z. Fan, X. Liu, C. Berro, E. Rauzy and L. Peng, Org. Biomol. Chem., 2007, 5, 1695-1701.

32. J. Wan, R. Zhu, Y. Xia, F. Qu, Q. Wu, G. Yang, J. Neyts and L. Peng, Tetrahedron Lett., 2006, 47, 6727-6731.

33. R. Zhu, PhD Thesis, Wuhan Univeristy, 2007.

34. F. J. Oliver, G. de la Rubia, V. Rolli, M. C. Ruiz-Ruiz, G. de Murcia and J. M.-d. Murcia, J. Biol. Chem., 1998, 273, 33533-33539.

35. A. R. D. Delbridge, S. Grabow, A. Strasser and D. L. Vaux, Nat. Rev. Cancer, 2016, 16, 99-109.

36. F. K. Chan, K. Moriwaki and M. J. De Rosa, Methods Mol. Biol., 2013, 979, 65-70. 37. Y. Xia, P. Rocchi, J. L. Iovanna and L. Peng, Drug Discov. Today, 2012, 17, 35-43. 38. G. Jego, A. Hazoumé, R. Seigneuric and C. Garrido, Cancer Lett., 2013, 332, $275-$ 285.

39. J. Wu, T. Liu, Z. Rios, Q. Mei, X. Lin and S. Cao, Trends Pharmacol. Sci., 2017, 38, 226-256.

40. R. Gomez-Pastor, E. T. Burchfiel and D. J. Thiele, Nat. Rev. Mol. Cell Biol., 2018, 19, 4-19.

41. C. Andrieu, D. Taieb, V. Baylot, S. Ettinger, P. Soubeyran, A. De-Thonel, C. Nelson, C. Garrido, A. So, L. Fazli, F. Bladou, M. Gleave, J. L. Iovanna and P. Rocchi, 
Oncogene, 2010, 29, 1883-1896.

42. Q. K. Shen, C. F. Liu, H. J. Zhang, Y. S. Tian and Z. S. Quan, Bioorg. Med. Chem. Lett., 2017, 27, 4871-4875.

43. J. Tirado-Rives and W. L. Jorgensen, J. Chem. Theory Comput., 2008, 4, 297-306. 44. M. J. Frisch, G. W. Trucks, H. B. Schlegel, G. E. Scuseria, M. A. Robb, J. R. Cheeseman, G. Scalmani, V. Barone, G.A. Petersson and H. Nakatsuji, et al. Gaussian 16 Rev. C.01, Wallingford, CT, 2016. 